\title{
Is phenotypic variation of blue tits (Parus caeruleus L.) in Mediterranean mainland and insular landscapes adaptive?
}

\author{
Jacques Blondel*, Philippe Perret, Paula C. Dias, \\ Marcel M. LAMBRECHTS
}

CEFE/CNRS, 1919 route de Mende, 34293 Montpellier Cedex 5, France

\begin{abstract}
Few empirical studies of bird populations have examined in detail how proximate and ultimate factors determine phenotypic variation in relation to smallscale environmental variation. This question has been addressed in the Mediterranean region, using blue tit (Parus caeruleus) populations living in habitat patches dominated either by deciduous (Quercus humilis) or evergreen $(Q$. ilex) oaks, which strongly differ in the timing and abundance of food resources. Our aim was threefold: 1) to analyse phenotypic variation and local differentiation of fitness-related life history traits on the scale of habitat mosaics within two different landscapes, one in mainland southern France and one on the island of Corsica; 2) to examine to what extent phenotypic variation is an ultimate response to local selection regimes and results in local adaptation; 3) to investigate whether phenotypic variation correlates with the genetic structure of populations. In the mainland landscape, where tits are assumed to disperse freely across habitat patches, little local differentiation of breeding traits has been found within a range of $c a 40 \mathrm{~km}$, suggesting gene swamping between populations. A molecular genetics study of populations within this landscape supported the hypothesis of a source-sink population structure with more birds immigrating from deciduous habitat patches to evergreen ones than the reverse. In a similar geographic configuration of habitats in Corsica, there was a higher phenotypic variation and a higher degree of population differentiation on a scale which is usually smaller than the dispersal range of blue tits. This difference between the mainland and Corsica is interpreted as resulting from reduced dispersal ranges of island birds and supports the divergence-with-gene-flow model of speciation.
\end{abstract}

phenotypic variation / blue tit / Mediterranean / deciduous / evergreen / Corsica / Aves

* Correspondence and reprints

E-mail: blondel@cefe.cnrs-mop.fr 
Résumé - La variation phénotypique des mésanges bleues (Parus caeruleus $\mathrm{L}$.) dans les paysages méditerranéens continentaux et insulaires est-elle adaptative ? Un problème fondamental et très actuel en biologie évolutive est l'étude du degré d'adaptation des organismes à leur environnement, ce degré étant déterminé par l'équilibre réalisé entre la spécialisation locale, qui est une réponse évolutive aux régimes locaux de sélection, et le brassage génétique. Malgré son importance théorique et appliquée à la gestion des espèces et des espaces, très peu d'études de cas ont abordé ce problème chez les vertébrés. Un objectif majeur est de faire la distinction entre les facteurs écologiques ou « immédiats » et les facteurs évolutifs ou «ultimes » qui déterminent la variation phénotypique observée en fonction d'une variation à petite échelle de l'environnement. Cette question a été abordée en région Méditerranéenne sur des populations de Mésange bleue (Parus caeruleus) qui habitent deux types d'habitats qui diffèrent fortement par l'abondance et la phénologie des ressources alimentaires exploitées par les mésanges, des forêts de Chêne pubescent (Quercus humilis) et des forêts de Chêne vert (Q. ilex). Le but du progamme est triple : 1) analyser la variation phénotypique de traits d'histoire de vie étroitement associés à la valeur sélective des organismes ; 2) examiner dans quelle mesure cette variation est une réponse évolutive aux régimes locaux de sélection, cas auquel elle se traduit par une spécialisation locale génétiquement fixée ; 3) examiner si cette variation est corrélée à la structuration génétique des populations. Le protocole d'étude se situe à deux échelles emboîtées d'espace et comprend deux paysages de même configuration géographique, l'un en Corse, l'autre sur le continent dans les environs de Montpellier (échelle inter-régionale). Chaque paysage comprend à son tour les deux types d'habitats, Chêne pubescent et Chêne vert (échelle intra-régionale). Dans le paysage continental où les mésanges sont supposées se disperser librement entre les deux types d'habitats, une faible différenciation des traits de reproduction, notamment de la date de ponte, indique qu'un brassage génétique important entre populations s'oppose à la spécialisation locale. Une étude de génétique moléculaire tend à confirmer l'hypothèse d'une structure populationnelle du type « source-puits ». Dans le paysage insulaire, la variation phénotypique des traits, notamment de la date de ponte, est plus élevée et correspond à une spécialisation étroite des populations à des habitats contrastés mais géographiquement très voisins. Cette différence entre le continent et la Corse est interprétée comme la conséquence d'une dispersion plus réduite chez les oiseaux insulaires, ce qui autorise une différenciation adaptative entre populations, même en présence d'un flux génique. Cette étude, qui est la première à démontrer chez des oiseaux aussi mobiles que des passereaux, une différenciation adaptative à une échelle d'espace très inférieure au rayon de dispersion des organismes, pose la question de l'identification et de la gestion de la diversité génétique, notamment en milieu insulaire.

variation phénotypique / mésange bleue / Méditerranée / caducifolié / sempervirent / Corse

\section{INTRODUCTION}

A basic problem in evolutionary biology is the degree of adaptedness of organisms to their environment, i.e. how the balance between local selection and 
gene flow determines the extent to which populations may become adapted to heterogeneous environments $[59,60]$. This problem has been addressed by Wright $[66,67]$ who gave much emphasis to the evolutionary interplay between gene flow and local specialisation through dispersal, founder effects, genetic drift and natural selection. Within most species, there is a large geographical variation in a variety of traits, often on very small spatial scales [28], but selection pressures determining this variation as well as its adaptive value have rarely been measured in detail. In the last decade, the effects of habitat heterogeneity on phenotypic and genetic variation of natural populations have received much attention, mostly based on the metapopulation concept $[35,36,44]$. In spite of a surge of interest in the evolution of local adaptation in populations, which is a challenge for understanding the impact of global changes and habitat fragmentation on the evolution of life-histories, surprisingly few studies have demonstrated the relationships between phenotypic variation and variation of selection pressures on a microgeographic scale [32,58]. The need for such studies has been enhanced by the development of a theoretical framework for investigating population dynamics, dispersal, gene flow and adaptation, as well as by the increasing utilisation of molecular techniques [14] to study the genetic differentiation of populations on different spatial scales.

Depending on the species-specific dispersal distance between birth and first reproduction, variation of biological traits much depends on geographical scale and environmental heterogeneity [4]. A crucial point is the ratio of scales of dispersal to the scales of selective pressures. If the range of dispersal of the organism is small relative to the scale of environmental heterogeneity, strong variation can occur over very short distances, especially if the landscape includes habitat types that differ in selection pressures for the target species. In that case, local specialisation, that is the evolution of traits that have been selected in a given environment and that do not change if the organism migrates into another environment, is likely to occur. On the other hand, if the range of dispersal of the organism is large relative to the scale of environmental heterogeneity, the geographical scale of trait variation relative to environmental variation is large, and phenotypic plasticity should be selected for. However, local maladaptation due to gene flow may occur if differences in habitat quality are combined with density-dependent habitat selection [63]. Thus, depending on its scale and patterns, habitat patchiness may lead either to local specialisation, phenotypic plasticity or local maladaptation through gene flow.

Although habitat-specific effects on demographic rates have been reported in different species of birds and mammals (Ref. in [52]), very few studies have reported non-adaptive trait variation in vertebrates (but see $[18,62]$ ). To our knowledge, no empirical studies of bird populations have addressed so far the questions of local specialisation, phenotypic plasticity and maladaptation in relation to small-scale variation of habitat quality and landscape structure. We will address these questions using the large observed phenotypic variation of 
blue tit (Parus caeruleus) populations in Mediterranean habitats from a longterm programme initiated 25 years ago (see [7]). Our programme includes three main steps: first, analyse the extent of phenotypic variation for various traits in habitat mosaics; second, examine to what extent local trait differentiation is a response to local selection pressures; third, study the relationship between the observed population differentiation of life-history traits and the genetic structure of populations. Using many results obtained over years as a background, this paper analyses the causes and consequences of phenotypic variation on different spatial scales, focusing on the differences in patterns of variation between Corsica and the mainland.

\section{STUDY SITES AND DATA COLLECTION}

The Mediterranean region is particularly suitable for investigating phenotypic variation because of its mosaic structure of landscapes which include well-defined habitat patches dominated in varying proportions by either deciduous (e.g. Quercus humilis) or evergreen (e.g. Q. ilex) oaks. A main feature of oaks in the Mediterranean region, which is a key point in our studies, is that the spring development of leaves and that of their associated folivorous arthropod fauna, mainly caterpillars, occur one month earlier in deciduous oaks than in evergreen oaks [9]. Moreover, the abundance of leaf-eating caterpillars is much lower in evergreen oaks, which renew only $30 \%$ of their foliage yearly, than in deciduous oaks. The one-month difference in the availability of caterpillars, the main prey for tits, is crucial because food supply has consistently been shown proximately and ultimately to determine fitness-related breeding traits such as laying date and clutch size $[2,8,26,38-40,46,50,57]$. Many observational and experimental studies have repeatedly shown that birds which best synchronise the nestling stage with the short period of maximal caterpillar abundance raise more young of better quality which therefore have a higher chance of being recruited in the population $[11,20,21,37]$. Therefore, we made much effort to measure the timing and abundance of the food supply in our study areas through routine collection in $0.50 \mathrm{~m} \times 0.50 \mathrm{~m}$ trays of the frass of caterpillars falling from the foliage of trees in spring (see [68] for methodological details).

In order to investigate the causes and consequences of the large phenotypic variation of life-history traits, we studied blue tit populations on different spatial scales, using nested levels of habitat variation. For this purpose, we chose two landscape mosaics, one in southern France, near Montpellier, and the other on the island of Corsica (inter-regional scale), each of them including habitat patches of either deciduous or evergreen trees (intra-regional scale). Within each of these regions between which blue tits do not disperse (the Corsican blue tit belongs to a separate subspecies, Parus caeruleus ogliastrae), five study areas, dominated either by deciduous (Quercus humilis, Alnus glutinosa) or by evergreen (Quercus ilex) trees, have been studied. They were located within a 


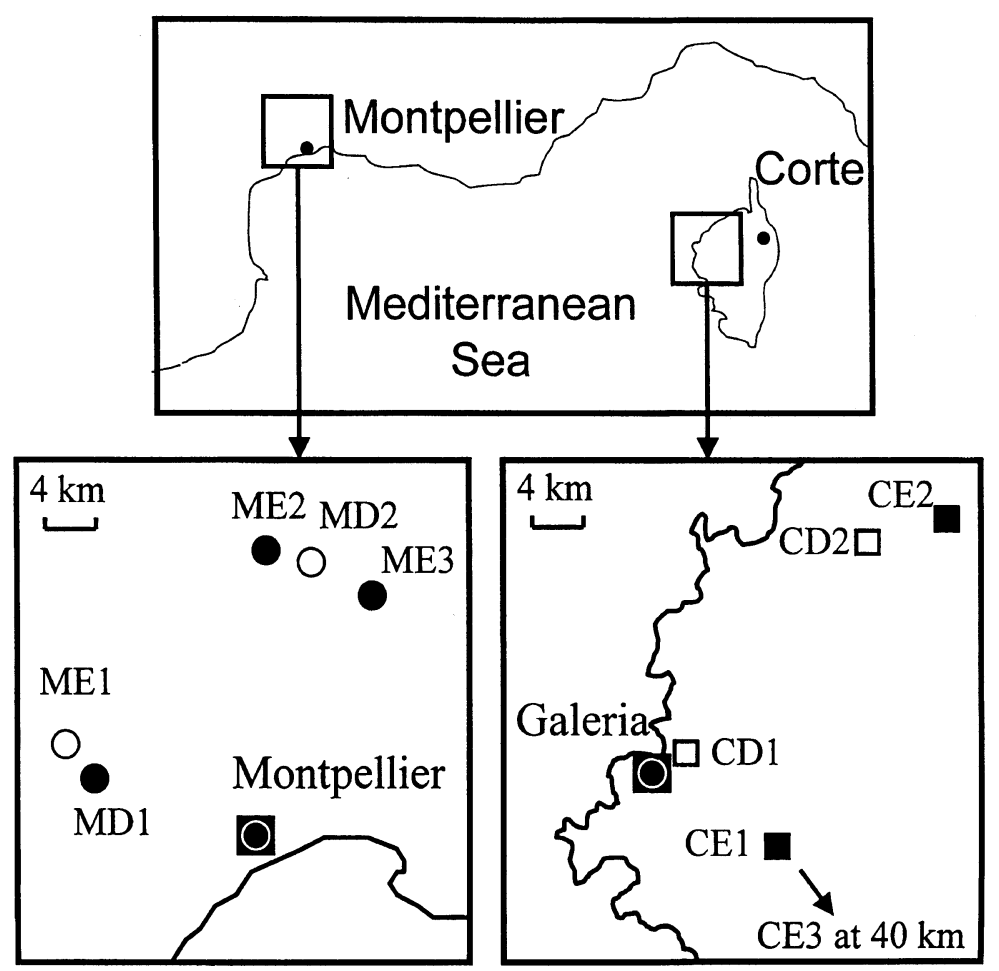

Figure 1. Location of the study sites in the mainland and the Corsican landscapes $(\mathrm{CE}=$ Corsican evergreen, $\mathrm{CD}=$ Corsican deciduous, $\mathrm{ME}=$ Mainland evergreen, $\mathrm{MD}=$ Mainland deciduous). Localities are Rouvière (MD1), Liouc (MD2), Puéchabon (ME1), Quissac (ME2), Vic (ME3), Pirio (CE1), Speloncato (CE2), Tavera (CE3), Galéria (CD1) and Muro (CD2).

range of a maximum of $40 \mathrm{~km}$ on the mainland and $60 \mathrm{~km}$ in Corsica (Fig. 1). This scale is much lower than the usual scale of inter-population variation in passerine birds [1]. The geographical configuration of landscapes was rather similar in the two regions but on a broad geographic scale deciduous trees are more common than evergreen trees on the mainland whereas the opposite is true in Corsica.

Breeding and morphometric parameters of blue tits were collected from birds breeding in nest-boxes which were erected in each study area at a density of ca 2 nest-boxes ha ${ }^{-1}$ (a total of 600 nest-boxes were available at the ten study sites). Nest-boxes were routinely checked at least once a week and laying date (first egg), clutch size, hatching date, number of hatchlings and fledglings were recorded. Adults were caught when nestlings were close to fledging, identified from their ring number if ringed, sexed, and aged. All adult birds were measured (body mass, wing length, tarsus length, bill length), as well as young 
birds just prior to fledging (see $[9,11,22,40,43]$ for details). The blue tit usually produces only one clutch per season but replaces a clutch which has been destroyed. Only genuine first clutches have been considered in this study.

\section{RESULTS}

\subsection{Patterns of trait variation on the between-region scale}

A considerable and unexpected variation for all the traits examined, including breeding traits $[5,9,40,41]$, behaviour (e.g. aggressiveness) [49], song structure $[24,25]$, and morphometry, has been found on the scale of the two regions combined, with a clear distinction between mainland and Corsican populations. Table I gives some examples of this variation. Figure 2 presents the mean laying date and clutch size in the 10 habitats considered in this study. On average, Corsican populations started laying later and produced smaller clutches than mainland populations (laying date: 8 May \pm 10 days vs. 28 April $\pm 18.5, P<0.0001$; clutch size: $7.1 \pm 1.7$ eggs vs. $9.6 \pm 1.6$ eggs, $P<0.0001$ on the mainland and in Corsica, respectively), but a key point is the much higher inter-population variation of laying date in Corsica than on the mainland. A comparative analysis of the within-region phenotypic variation between the mainland and Corsica using Bartlett's test of equality of variance [61] revealed a remarkably higher differentiation for this trait in Corsica than on the mainland $\left(\chi^{2}=165.24, P<0.0001\right)$. In the mainland landscape, birds of the five study sites started egg laying within a range of 9 days as compared to 29 days in Corsica. It was in Corsica, between a population breeding in evergreen oaks (CE1 in Fig. 1) and a population breeding in deciduous oaks (CD2), that we observed the largest difference in laying date among the 10 Mediterranean populations considered in this study (Figs. 2,3). Because the differences between the two regions in inter-population differentiation were much smaller for other traits, we will mostly focus on laying date which is crucial for breeding success because it conditions the degree of synchronisation between the period of maximum food abundance and the period of maximum food demand from the nestlings.

Blue tits started egg laying on average 3-4 weeks earlier and clutch size was $30-40 \%$ higher in a habitat dominated by deciduous oaks on the mainland (MD1 in Tab. I and Figs. 2 and 3) than in a habitat dominated by evergreen oaks in Corsica (CE1) $[9,40]$. In both habitats, blue tits fairly well synchronised their nestling stage with the brief window ( $c a 2$ weeks) of maximal caterpillar abundance, and hence enjoyed a good breeding success. Common garden experiments in aviaries have demonstrated that the differences in laying date between these two populations were genetically based and corresponded to adaptive responses to the consistent differences in the local timing of food availability $[12,41,42]$. 
Table I. Examples of phenotypic variation (mean \pm 1 standard deviation, sample sizes in parentheses) of breeding and morphometric traits of Blue tits in four Mediterranean habitats on the mainland and in Corsica. Habitat effects are highly significant for all traits $(P<0.0001)$. See Figure 1 for the identification of habitats.

\begin{tabular}{ccccc}
\hline & \multicolumn{2}{c}{ Mainland } & \multicolumn{2}{c}{ Corsica } \\
\cline { 2 - 5 } Traits & $\begin{array}{c}\text { Deciduous } \\
\text { (MD1) }\end{array}$ & $\begin{array}{c}\text { Evergreen } \\
(\mathrm{ME} 1)\end{array}$ & $\begin{array}{c}\text { Deciduous } \\
(\mathrm{CD} 2)\end{array}$ & $\begin{array}{c}\text { Evergreen } \\
(\mathrm{CE} 1)\end{array}$ \\
\cline { 2 - 5 } Laying date & $37.8 \pm 8.6(380)$ & $50.5 \pm 11.9(53)$ & $38.0 \pm 9.7(183)$ & $73.8 \pm 6.5(256)$ \\
Clutch size & $9.8 \pm 1.6(380)$ & $8.5 \pm 1.3(53)$ & $8.5 \pm 1.5(183)$ & $6.3 \pm 1.2(256)$ \\
Wing length & & & & \\
males & $66.6 \pm 1.8(266)$ & $66.4 \pm 2.0(41)$ & $63.2 \pm 1.5(215)$ & $63.6 \pm 1.6(253)$ \\
females & $63.8 \pm 1.5(293)$ & $63.9 \pm 1.6(36)$ & $60.8 \pm 1.5(144)$ & $60.7 \pm 1.2(237)$ \\
Body mass & & & & \\
males & $11.2 \pm 0.5(266)$ & $10.8 \pm 0.6(41)$ & $10.0 \pm 0.5(215)$ & $9.3 \pm 0.4(253)$ \\
females & $10.8 \pm 0.5(293)$ & $10.9 \pm 0.6(36)$ & $9.7 \pm 0.4(144)$ & $9.2 \pm 0.5(237)$ \\
Tarsus length & & & & \\
males & $17.0 \pm 0.5(266)$ & $16.8 \pm 0.5(41)$ & $16.5 \pm 035(215)$ & $16.2 \pm 0.5(253)$ \\
females & $16.4 \pm 0.4(293)$ & $16.3 \pm 0.5(36)$ & $16.0 \pm 0.4(144)$ & $15.8 \pm 0.5(237)$ \\
Bill length & & & & \\
males & $9.8 \pm 0.4(266)$ & $9.8 \pm 0.4(41)$ & $9.5 \pm 0.4(215)$ & $9.6 \pm 0.4(253)$ \\
females & $9.8 \pm 0.5(293)$ & $9.9 \pm 0.4(36)$ & $9.6 \pm 0.5(144)$ & $9.7 \pm 0.4(237)$ \\
\hline
\end{tabular}

In the two regions, the caterpillar peak-date occurred approximately at the same date in each habitat type with a one-month delay in evergreen oaks as compared to deciduous oaks (Figs. 2,3), so that the optimal laying date (dotted lines in Fig. 2) is similar on the mainland and in Corsica for each habitat type. This means that if all populations were equally well adapted to the local food schedule, all populations in evergreen habitats should breed at a similar date in any given year, that is one month later than all populations living in deciduous habitats, both on the mainland and in Corsica. Figure 2 shows that this is not the case: on the mainland the three populations in evergreen habitats (ME1, ME2, ME3) started earlier than expected assuming local specialisation. In Corsica, one population in a deciduous habitat (CD1) started to breed later, and one population in an evergreen habitat (CE2) started to breed earlier than expected.

\subsection{Inter-habitat phenotypic and genetic variation within the mainland landscape}

In contrast to the considerable differences in breeding traits between the deciduous mainland habitat (MD1) and the evergreen Corsican habitat (CE1) 

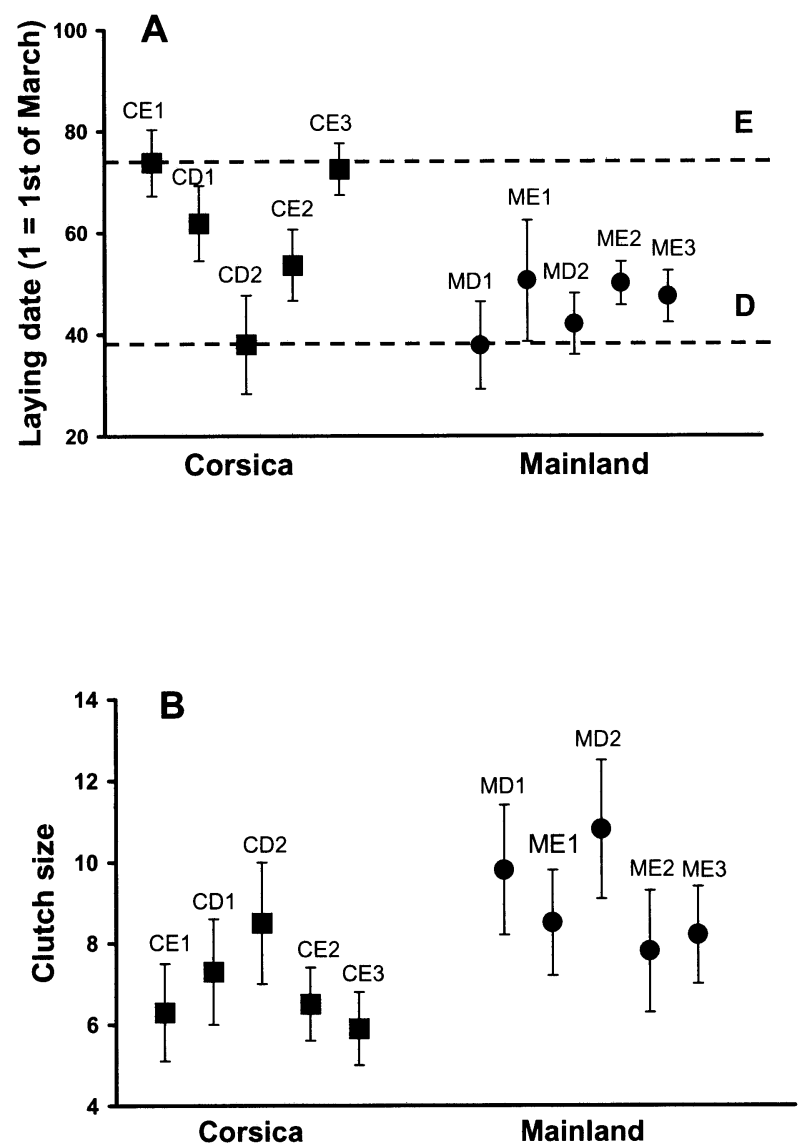

Figure 2. A) Mean laying date (in "March-date", i.e. $32=1$ st of April) in the mainland and the Corsican habitats. The horizontal dotted lines indicate the best date for onset of breeding relative to resource availability in deciduous habitats (D) and in evergreen habitats $(\mathrm{E})$, respectively. Vertical bars $=1$ standard deviation. B) Variation of clutch size in the Corsican and mainland habitats. See text.

reported above, inter-habitat differences in these traits within the mainland landscape were much smaller [9,22] (see Fig. 2 for laying date), as illustrated in Figure 3. For birds breeding in mainland evergreen habitats, this necessarily resulted in a mismatching between the maximum peak-date of food availability and the nestling stage and, as a consequence, a lower breeding success $[9,15,20,22]$. Small differences in laying date within the mainland mosaic have been hypothesised to result from gene flow from birds adapted to deciduous oaks migrating in evergreen oaks $[9,13,21]$. Assuming that individuals freely disperse across habitat patches, which by no means implies that dispersal is random, we hypothesised that this observed maladaptation between the nestling period and food abundance in evergreen habitat patches resulted in a 

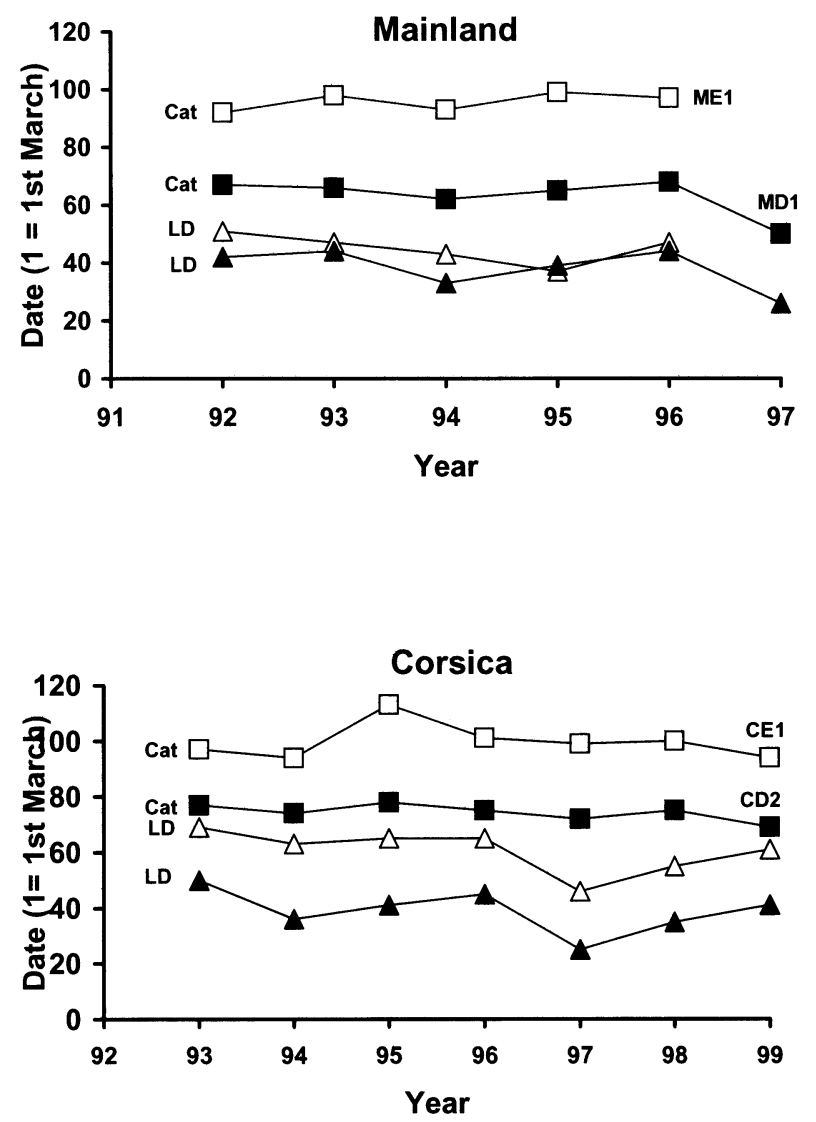

Figure 3. Relationship over years between the peak of caterpillar abundance (squares, Cat) and laying date of blue tits (triangles, LD) in evergreen (open symbols, ME1 and CE1) and deciduous habitats (black symbols, MD1 and CD2) on the mainland and in Corsica. Note the one-month difference in caterpillar peak-date between evergreen and deciduous habitats, the mismatching of tits in the evergreen habitat on the mainland, and the nice synchronisation of the two populations in Corsica.

"source-sink" population structure [51] which involves asymmetrical dispersal from the commoner habitats (source), where birds are adapted to the local timing of food availability, to the less common habitat (sink), where the timing of food availability occurs later [13,21,23]. Logically, we assigned deciduous Downy oak habitats as sources and evergreen Holm oak habitats as sinks because all population and breeding parameters, e.g. population sizes, breeding success and quality of offspring, were higher in the former than in the latter. Hence source populations produce an excess of individuals that are expected to disperse to smaller populations in less optimal sink habitats, thus preventing them from extinction $[20,21]$. 
To test this hypothesis, we combined molecular techniques and population genetics using minisatellite single locus probes $[23,65]$. Genetic differentiation within and among populations and numbers of migrants were tested with the GENEPOP software [53]. The "source-sink" hypothesis [51,52] generates three predictions: 1) assuming that source populations are differentiated on the scale of the landscape, we expected a significant differentiation among sink habitats, but not between source and sink habitats. 2) Estimates of number of migrants between source and sink habitats should be higher than among source habitats or among sink habitats, and number of migrants should be higher among source than among sink habitats. 3) Linkage disequilibrium should be higher in sink than in source habitats because of immigration of birds from distinct and differentiated source habitats (generalized Wahlund effect). Seven supposedly source (deciduous) and sink (evergreen) habitats were sampled on the mainland in habitats mentioned in Figure 1 or within a range of $5 \mathrm{~km}$ around them as well as one additional evergreen site in Corsica used as an outgroup (see [23] for details).

Results showed that 1) Populations were significantly $(P<0.002)$ differentiated on the scale of the landscape, including when only one type of habitat was considered. Differentiation among source and among sink habitats was detected on a scale of less than 40 and $5 \mathrm{~km}$, respectively, but there was no significant differentiation between sources and sinks. 2) Gene flow was ranked in the following decreasing order: between source and sink habitats, among source habitats and then among sink habitats, which supports the prediction 2 stated above. $3)$ Linkage disequilibrium was significantly higher $(P<0.0001)$ in evergreen (sink) than in deciduous (source) habitats, which supports prediction 3 [23]. These results are consistent with the observed contrasting demographic patterns of populations and support a source-sink population structure within the mainland mosaic of habitat patches.

\subsection{Inter-habitat phenotypic and genetic variation within the Corsican landscape}

The next step was to explain why phenotypic variation is much higher in Corsica than on the mainland, keeping in mind that 1) the mainland and the Corsican landscapes are reasonably well matched in terms of geographic configuration of habitat patches, and 2) there is a large, genetically determined, mainland deciduous vs. Corsican evergreen differentiation of laying date (between-region scale, see above). Following the same rationale as on the mainland, we predicted that blue tits in deciduous habitats in Corsica would also be maladapted, but the other way around, as a result of gene flow from the more common evergreen habitat patches (assumed to be sources) to the less common deciduous habitat patches (assumed to be sinks). We predicted that blue tits in the deciduous habitat would start to breed well after the local peakdate of caterpillars, and therefore would have a low breeding success. To test 
this hypothesis we studied blue tits in several evergreen and deciduous habitat patches. One pair of study plots was located in a valley dominated by evergreen oaks. It included the Pirio site (CE1 in Fig. 1) and a small woodlot of alder (Alnus glutinosa) $9 \mathrm{~km}$ apart (Galeria site, CD1). Another pair of sites was located near Calvi ca $25 \mathrm{~km}$ from the Pirio valley. One site was a patch of Downy oaks (CD2 in Figs. 1 and 2) and the other a patch of Holm oaks (CE2). A fifth site (CE3) was located in an evergreen forest $40 \mathrm{~km}$ from the Fango valley. In the first pair of sites (which are in the same valley), our predictions were more or less supported. Birds in the deciduous habitat patch at Galeria (CD1) started to breed much later than expected from the local leafing phenology of the trees [21] (see Fig. 2). We concluded that the two populations within this valley (CE1 and CD1) presented the same patterns as those observed in the mainland mosaic, that is a mistiming of laying date in the less common habitat attributable to gene flow.

On the other hand, in the second pair of sites, patterns strikingly and unexpectedly differed. In the Muro site (CD2 in Figs. 1 and 2), the timing of reproduction was quite similar to that observed in the mainland deciduous habitat (MD1). Blue tits in this habitat matched the period of food availability as well as those of Pirio (Figs. 2, 3), with a one-month delay of laying date, paralleling the one-month delay in the period of peak abundance of caterpillars. This clearly indicates that tits in this population evolved their breeding biology in response to the local patterns of food variation $[10,40]$. In addition, the two populations significantly differed in all measured demographic and morphometric traits. Experiments in aviaries also showed that the two populations had quite different reaction norms in laying date, which suggests large genetic and/or physiological differences between them [10]. Thus these two populations on the island behave in the same way as genetically isolated mainland and island populations, providing a striking, and as far as we know the first, example in birds of an adaptive response of suites of life history traits to habitat-specific selection regimes that operate on a scale which is much smaller than the scale of potential gene flow.

However, taken alone, these patterns are not proof of reproductive isolation because extensive phenotypic variation may occur in the presence of a relatively large amount of gene flow. In order to investigate to what extent the high observed phenotypic differentiation of Corsican blue tits relates to genetic variation, we carried out a genetic analysis of population structure using four micro-satellite loci [33]. Blood samples were collected in the two populations in 1996 and 1998 (34 and 28 in 1996, and 26 and 27 in 1998 at Pirio and Muro, respectively), and we used four micro-satellite DNA primers (see [33] for methodological details). Using GENEPOP software [53], we tested for panmixia and for genotypic linkage disequilibrium within populations, for genetic differentiation between populations, and also for isolation by distance between populations. In contrast to the large inter-population phenotypic variation of 
Table II. Genotypic differentiation between the Pirio (CE1) and Muro (CD2) populations in 1996 and 1998, using four micro-satellite markers (Garnier, 1999). $P=$ probability, $\mathrm{SD}=$ standard deviation, $F_{\text {st }}=$ Wright's fixation index.

\begin{tabular}{llllr}
\hline Year & Locus & $P$ & SD & \multicolumn{1}{c}{$F_{\text {st }}$} \\
\hline \multirow{2}{*}{1996} & PC2 & 0.1155 & 0.0024 & 0.0048 \\
& PC3 & 0.3132 & 0.0039 & -0.0086 \\
& PC7 & 0.2533 & 0.0035 & -0.0063 \\
& PK12 & 0.6865 & 0.0038 & -0.0028 \\
& All & 0.2555 & - & -0.0033 \\
1998 & & & & \\
& PC2 & 0.0021 & 0.0002 & 0.0406 \\
& PC3 & 0.2379 & 0.0036 & 0.0083 \\
& PC7 & 0.3870 & 0.0039 & 0.0012 \\
& PK12 & 0.5479 & 0.0039 & -0.0002 \\
& All & 0.0187 & - & 0.0123 \\
& & & & \\
$1996-1998$ & All & $\chi_{4}^{2}=10.69$ & & \\
& & $P=0.036$ & & \\
\hline
\end{tabular}

life history traits between the Muro (CD2) and Pirio (CE1) populations, a genetic differentiation using neutral markers was hardly detectable (Tab. II). Of the four markers investigated, only PC2 showed a significant differentiation in 1998, but not in 1996. However, the differentiation became significant when the two years were pooled (Fisher test). In any case, the magnitude of genetic differentiation was low, which suggests a substantial exchange of genes between the two populations.

\section{DISCUSSION AND CONCLUSION}

We mostly investigated in this paper the variation of laying date which is the most important trait for fitness because all components of breeding performance depend on a good matching between the nestling stage and the period of maximum food abundance. Variation in the timing and abundance of food resources (the food schedule) shapes all aspects of population behaviour and is a major component of phenotypic differentiation and adaptation to different environments $[32,55]$. Therefore, a strong inter-population variation in laying date is particularly meaningful because suites of other traits, including morphometric traits, are likely to covary with laying date.

From the degree of synchronisation between laying date and the peak of caterpillar abundance, populations are either finely adapted to the local food schedule or clearly maladapted. Populations in which the onset of breeding 
falls around the optimal date with respect to food availability (dotted horizontal lines in Fig. 2, see also Fig. 3) are finely adapted to their local habitat. This is the case for three populations in Corsica and two populations on the mainland. All the other populations more or less mismatch the optimal time of reproduction and we interpret this mismatching as a consequence of gene flow, eventually leading to a source-sink population structure as suggested by molecular studies on the mainland. The somewhat intermediate position of several populations between the optimal time in the two types of habitats is an indication of the extent of phenotypic plasticity of each population. Phenotypic plasticity can to some extent compensate for the difference between the two habitat types but the "window" of phenotypic plasticity is not large enough to compensate fully for such a large difference in the timing of food resources. This interpretation is supported by the fact that the large difference in the onset of breeding between a mainland deciduous habitat (MD1) and an evergreen Corsican habitat (CE1) has been experimentally demonstrated to result from adaptive variation in responses of populations to photoperiod [41].

An interesting issue to discuss is the striking difference in inter-population variation of laying date between the mainland and the Corsican mosaics of habitats. In particular, the fact that the populations CE1 and CD2 (hereafter called Pirio and Muro, respectively), which are only $25 \mathrm{~km}$ apart, had an equally good synchronisation of laying date to the food schedule was unexpected from previous results on the mainland (see Fig. 2). Such a large difference in laying date between two adjacent conspecific populations is quite exceptional in birds, and, as far as we know, had never been reported before [10]. Since the mainland and Corsican landscapes reasonably well match in terms of geographic configuration and habitat types, something other than landscape structure must be involved to explain these patterns. The most likely explanation is that dispersal rates differ between mainland and insular blue tits. What sets the Corsican populations apart from those of the mainland and explains the larger phenotypic variation of traits is a reduced dispersal in island birds [19] which is a component of the insular syndrome which has been shown to occur in Corsican birds [6]. A stronger habitat fidelity in Corsica than on the mainland combined with low dispersal rates and presumably assortative mating explains reproductive isolation and population differentiation as a consequence of low dispersal rates on the island.

In vertebrates, population differentiation of phenotypes on a microgeographic scale has rarely been proven to be adaptive [32,58], although local variation of fitness-related traits as a result of resource-based divergent selection expresses the process of adaptation $[29,32,55]$. In vertebrates, examples of withinspecies genetically-based microgeographic variation relating suites of covarying traits to environmental factors have been provided in fishes [29] and mammal species $[16,45,48]$, but in such mobile organisms as birds, local population differentiation as a response to divergent selection pressures is supposed to be rare on a scale which is smaller than the dispersal range of individuals, because of 
the homogenising effects of gene flow. However, theory predicts that if the environment is relatively constant in space, maximising mean fitness results in an adaptive differentiation of specialised phenotypes because environmental constancy favours the evolution of specialisation [31], even if gene flow is in excess of a few migrants per generation [3]. Our findings on Corsican blue tits support these predictions by demonstrating that the Pirio and Muro populations are highly specialised to their local habitats and differ markedly in demographic and morphometric traits. Divergent selection pressures in the two populations are presumably sufficiently strong to outweigh the effects of gene flow, if any $[27,59,60]$. This is an illustration of the "divergence-with-gene-flow" model of speciation $[30,47]$ which supports the contention that reproductive isolation can evolve between populations connected by gene flow whenever divergent selection is strong relative to gene flow [56]. We argue that, whatever the extent of dispersal between the two populations, gene flow between them must be low, possibly because of premating isolating mechanisms, e.g. physiological or behavioural, which depend on traits that diverge in association with the exploitation of different habitats and resources.

Given the large phenotypic variation of life history traits between the two regions, the small degree of genetic differentiation we observed between Pirio and Muro was surprising if we do not accept the previous explanation. There are several explanations for this hardly detectable differentiation. First, more markers and larger sample sizes could yield different results and enhance the power of statistical analyses to detect possible genetic differentiation. Another explanation is that neutral markers have not yet tracked the evolution of diverging suites of traits because it has been too recent and/or too rapid. Although microsatellites are among the most rapidly evolving repetitive markers and hence should be sensitive for detecting intraspecific differentiation, adaptive evolution at gene combinations determining fitness-related traits have occurred exceptionally quickly with little change occurring in the neutral regions of the genome. Such an explanation has been proposed to explain the low genetic differentiation among well-differentiated populations of cuckoos (egg colour of cuckoo gentes) [34] and among sympatric morphs of the Arctic charr (Salvinus alpinus) in Iceland [17]. This interpretation is supported by the fact that the extant landscape structure of Corsica is relatively recent as a result of longlasting human impact on the vegetation. Holm oak forests did not occur in Corsica before $\mathrm{ca} 6000 \mathrm{BP}$ and have been favoured by man at the expense of deciduous forests ([54] and A. Reille, person. comm.). Although it is extremely difficult to reconstruct the past history of forests in Corsica, it is likely that the mosaic-structure of landscapes as it stands today is quite recent. This could explain why genomic differentiation is still low in spite of the evolution of distinct ecological morphs. Interestingly, the trait that most rapidly evolved is laying date, a trait with usually high additive genetic variance $\left(h^{2}=0.33\right.$ in the Pirio population) and can evolve within a few generations only when subject to strong directional selection [64]. Likewise, it could be that other 
traits have differentiated little so far because of lower selection pressures on traits that are less crucial for fitness than laying date.

This study of phenotypic variation on large spatial scales emphasises that geographic proximity does not necessarily imply similar adaptation, as is often assumed in bird populations, and that adjacent populations may be ecologically very different but genetically quite similar. Most vertebrate populations in natural landscapes are open, dynamically interacting entities, and this may be a key aspect of their persistence in the face of spatial and temporal variation in the environment. However, this example of "nested insularity" highlights the importance of considering singular evolutionary pathways of island populations for assessing biodiversity patterns, which is of importance for conservation issues. Comparing the responses of less dispersive island birds and highly dispersive mainland birds to similar spatial diversity of habitats gives us a practical demonstration of the relationships between dispersal, spatially variable selection and local adaptation. One interesting message of this study is the changes in patterns of biodiversity on islands: a decrease in inter-specific diversity in impoverished insular biota is compensated by an increase in intraspecific diversity.

\section{ACKNOWLEDGEMENTS}

We thank Stéphane Garnier for his contribution to molecular studies and Marc Gibernau for statistical help. Marie-José Galan, Marie Maistre, Mireille Son and many students contributed to field work and data management. Three referees gave interesting comments and suggestions. This programme was supported by a grant from the Bureau des ressources génétiques (Grant $\mathrm{N}^{\circ} \mathrm{A} 00680$ SRAE-97117).

\section{REFERENCES}

[1] Avise J.C., Molecular Markers, Natural History and Evolution, Chapman and Hall, New York, London, 1994.

[2] Banbura J., Blondel J., de Wilde-Lambrechts H., Galan M.J., Nestling diet variation in an insular Mediterranean population of Blue Tits Parus caeruleus: Effects of years, territories and individuals, Oecol. 100 (1994) 413-420.

[3] Barton N.H., Whitlock M.C., The evolution of metapopulations, in: Hanski I.A., Gilpin M.E. (Eds.), Metapopulation Biology. Ecology, Genetics, and Evolution, Academic Press, London, 1997, pp. 183-210.

[4] Bell G., Lechowicz M.J., Appenzeller A., Chandler M., Deblois E., Jackson L., Mackenzie B., Preziosi R., Schallenberg M., Tinker N., The spatial structure of the physical environment, Oecol. 96 (1993) 114-121. 
[5] Blondel J., Breeding strategies of the Blue tit and the Coal tit (Parus) in mainland and island Mediterranean habitats: A comparison, J. Anim. Ecol. 54 (1985) 531-556.

[6] Blondel J., Chessel D., Frochot B., Bird species impoverishment, niche expansion and density inflation in Mediterranean island habitats, Ecology 69 (1988) 1899-1917.

[7] Blondel J., Clamens A., Cramm P., Gaubert H., Isenmann P., Population studies of tits in the Mediterranean region, Ardea 75 (1987) 21-34.

[8] Blondel J., Dervieux A., Maistre M., Perret P., Feeding ecology and life history variation of the Blue Tit in Mediterranean deciduous and sclerophyllous habitats, Oecol. 88 (1991) 9-14.

[9] Blondel J., Dias P., Maistre M., Perret P., Habitat heterogeneity and life history variation of Mediterranean Tits, The Auk 110 (1993) 511-520.

[10] Blondel J., Dias P.C., Perret P., Maistre M., Lambrechts M.M., Selectionbased biodiversity at a small spatial scale in an insular bird, Science 285 (1999) 1399-1402.

[11] Blondel J., Maistre M., Perret P., Hurtrez-Boussès S., Lambrechts M.M., Is the small clutch size of a Corsican Blue tit population optimal?, Oecol. 117 (1998) 80-89.

[12] Blondel J., Perret P., Maistre M., On the genetical basis of laying date in an island population of Blue Tit, J. Evol. Biol. 3 (1990) 469-475.

[13] Blondel J., Perret P., Maistre M., Dias P., Do harlequin Mediterranean environments function as source sink for Blue Tits (Parus caeruleus)?, Landsc. Ecol. 6 (1992) 213-219.

[14] Burke T., Rainey W.E., White T.J., Molecular variation and ecological problems, in: Berry R.J., Crawford T.J., Hewitt G.M. (Eds.), Genes in Ecology, Blackwell Scientific Publications, Oxford, 1992, pp. 229-254.

[15] Cramm P., La reproduction des Mésanges dans une chênaie verte du Languedoc, Alauda 52 (1982) 347-360.

[16] Daly J.C., Patton J.L., Dispersal, gene flow, and allelic diversity between local populations of Thomomys bottae pocket gophers in the coastal ranges of California, Evolution 44 (1990) 1283-1294.

[17] Danzmann R.G., Ferguson M.M., Skulason S., Snorrason S.S., Noakes D.L.G., Mirochondrial DNA diversity among 4 sympatric morphs of Arctic Charr Salvelinus alpinus L. from Thingvallavatn, Iceland, J. Fish Biol. 39 (1991) 649.

[18] Dhondt A.A., Adriaensen F., Matthysen E., Kempenaers B., Nonadaptive clutch sizes in tits, Nature 348 (1990) 723-725.

[19] Diamond J.M., Flightlessness and fear of flying in island species, Nature 293 (1983) 507-508.

[20] Dias P.C., Blondel J., Breeding time, food supply and fitness components in Mediterranean blue tits, Parus caeruleus, Ibis 138 (1996) 108-113.

[21] Dias P.C., Blondel J., Local specialization and maladaptation in Mediterranean blue tits, Parus caeruleus, Oecol. 107 (1996) 79-86.

[22] Dias P.C., Meunier F., Beltra S., Cartan-Son M., Blue tits in Mediterranean habitat mosaics, Ardea 82 (1994) 363-372.

[23] Dias P.C., Verheyen G.R., Raymond M., Source-sink populations in Mediterranean blue tits: evidence using single-locus minisatellite probes, J. Evol. Biol. 9 (1996) 965-978. 
[24] Doutrelant C., Aubin T., Hitier S., Lambrechts M.M., Two distinct song populations of blue tit Parus caeruleus in the French Mediterranean, Bioacoustics 9 (1998) 1-16.

[25] Doutrelant C., Leitao A., Giorgi M., Lambrechts M.M., Geographical variation in blue tit song, the result of an adjustment to vegetation type?, Behaviour 136 (1999) 481-493.

[26] Drent R.H., Daan S., The prudent parent: energetic adjustments in avian breeding, Ardea 68 (1980) 225-252.

[27] Endler J.A., Geographic variation, Speciation, and Clines, Princeton University Press, Princeton, 1977.

[28] Endler J.A., Genetic heterogeneity and ecology, in: Berry R.J., Crawford T.J., Hewitt G.M. (Eds.), Genes in Ecology, Blackwell Scientific Publications, Oxford, 1992, pp. $315-334$.

[29] Endler J.A., Multiple-trait coevolution and environmental gradients in guppies, Trends Ecol. Evol. 10 (1995) 22-29.

[30] Felsenstein J., Skepticism towards Santa Rosalia, or why there are so few kinds of animals, Evolution 35 (1981) 124-138.

[31] Futuyma D.J., Moreno G., The evolution of ecological specialization, Annu. Rev. Ecol. Syst. 19 (1988) 207-233.

[32] Garland T., Jr., Adolph S.C., Physiological differentiation of vertebrate populations, Annu. Rev. Ecol. Syst. 22 (1991) 193-228.

[33] Garnier S., Structuration spatiale des populations de mésange bleue Parus caeruleus en Corse. DEA, Université Montpellier II, 1999.

[34] Gibbs H.L., de Brooke L., Davies N.B., Analysis of genetic differentiation of host races of the common cuckoo Cuculus canorus using mitochondrial and microsatellite DNA variation, Proc. R. Soc. Lond. [Biol.] 263 (1996) 89-96.

[35] Hanski I.A., Gilpin M.E., Metapopulation Biology: Ecology, Genetics and Evolution, Academic Press, New York, 1997.

[36] Hastings A., Harrison S., Metapopulation dynamics and genetics, Annu. Rev. Ecol. Syst. 25 (1994) 167-188.

[37] Isenmann P., Cramm P., Clamens A., Étude comparée de l'adaptation des mésanges du genre Parus aux différentes essences forestières du Bassin méditerranéen occidental, Rev. Ecol. (Terre et Vie), Suppl. 4 (1987) 17-25.

[38] Klomp H., The determination of clutch-size in birds. A review, Ardea 58 (1970) $1-124$.

[39] Lack D., Population Studies of Birds, Clarendon Press, Oxford, 1966.

[40] Lambrechts M.M., Blondel J., Hurtrez-Boussès S., Maistre M., Perret P., Adaptive inter-population differences in Blue Tit life-history traits on Corsica, Evol. Ecol. 11 (1997) 599-612.

[41] Lambrechts M.M., Blondel J., Maistre M., Perret P., A single response mechanism is responsible for evolutionary adaptive variation in a bird's laying date, Proc. Natl. Acad. Sci. USA 94 (1997) 5153-5155.

[42] Lambrechts M.M., Dias P.C., Differences in the onset of laying between island and mainland Mediterranean blue tits Parus caeruleus: Phenotypic plasticity or genetic differences?, Ibis 135 (1993) 451-455.

[43] Lambrechts M.M., Perret P., Maistre M., Blondel J., Do experiments with captive non-domesticated animals make sense without population field studies? 
A case study with blue tits' breeding time, Proc. R. Soc. Lond. [Biol.] 266 (1999) 1311-1315.

[44] Levins R., Some demographic and genetic consequences of environmental heterogeneity for biological control, Bull. Entomol. Soc. Am. 15 (1969) 236-240.

[45] Lynch C.B., Genetic basis of cold adaptation in laboratory and wild mice Mus domesticus, in: Heller H.C., Musacchia X.J., Wang L.C.H. (Eds.), Living in the Cold: Physiological and Biochemical Adaptations, Elsevier, New York, 1986, pp. $497-504$.

[46] Martin T.E., Food as a limit on breeding birds: A life-history perspective, Annu. Rev. Ecol. Syst. 18 (1987) 453-487.

[47] Maynard Smith J., Sympatric speciation, Am. Nat. 100 (1966) 637-650.

[48] Nevo E., Evolutionary behavior genetics in active speciation and adaptation of fossorial mole rats, in: Montalenti G., Tecce G. (Eds.), Variability and Behavioral Evolution, Academia Nazionale dei Lincei, Rome, 1986, pp. 39-109.

[49] Perret P., Blondel J., Experimental evidence of the territorial defense hypothesis in insular Blue Tits, Experientia 49 (1993) 94-98.

[50] Perrins C.M., Population fluctuations and clutch-size in the great tit, Parus major L., J. Anim. Ecol. 34 (1965) 601-647.

[51] Pulliam H.R., Source, sinks, and population regulation, Am. Nat. 132 (1988) 652-661.

[52] Pulliam H.R., Danielson B.J., Sources, sinks, and habitat selection: A landscape perspective on population dynamics, Am. Nat. 137 (1991) S50-S66.

[53] Raymond M., Rousset F., GENEPOP (version 1.2): Population genetics software for exact tests and ecumenicism, J. Hered. 86 (1995) 248-249.

[54] Reille M., New pollen-analytical researches in Corsica: the problem of Quercus ilex L. and Erica arborea L., the origin of Pinus halepensis Miller forests, New Phytol. 122 (1992) 359-278.

[55] Reznick D.A., Bryga H., Endler J.A., Experimentally induced life-history evolution in a natural population, Nature 346 (1990) 357-359.

[56] Rice W.R., Hostert E.E., Laboratory experiments on speciation: What have we learned in 40 years?, Evolution 47 (1993) 1637-1653.

[57] Ricklefs R.E., Avian demography, Curr. Ornithol. 1 (1983) 1-32.

[58] Schluter D., Ecological causes of adaptive radiation, Am. Nat. 148 (1996) S40-S64.

[59] Slatkin M.K., Gene flow and the geographic structure of natural populations, Science 236 (1987) 787-792.

[60] Slatkin M.K., Gene flow and population structure, in: Real L.A. (Ed.), Ecological Genetics, Princeton Univ. Press, Princeton, 1994, pp. 3-17.

[61] Snedecor G.W., Cochran W.G., Statistical Methods, $7^{\text {th }}$ ed., The Iowa State University Press, Ames, Iowa, 1980.

[62] Stearns S.C., Sage R.D., Maladaptation in a marginal population of mosquitofish, Gambusia affinis, Evolution 34 (1980) 65-75.

[63] Thompson J.D., Phenotypic plasticity as a component of evolutionary change, Trends Ecol. Evol. 6 (1991) 246-249.

[64] van Noordwijk A.J., van Balen J.H., Scharloo W., Genetic variation in the timing of reproduction in the Great Tit, Oecol. 49 (1981) 158-166. 
[65] Verheyen G.R., Kempenaers B., Burke T., Van den Broeck M., Van Broeckhoven C., Dhondt A.A., Identification of hypervariable single locus minisatellite DNA probes for the Blue Tit (Parus caeruleus), Mol. Ecol. 3 (1994) 137-143.

[66] Wright S., Breeding structure of populations in relation to speciation, Am. Nat. 74 (1940) 232-248.

[67] Wright S., Evolution and the Genetics of Populations. IV. Variability Within and Among Populations, Chicago Univ. Press, Chicago, 1978.

[68] Zandt H., Strijkstra A., Blondel J., van Balen H., Food in two Mediterranean Blue Tit populations: Do differences in caterpillar availability explain differences in timing of the breeding season, in: Blondel J., Gosler A., Lebreton J.D., McCleery R. (Eds.), Population Biology of Passerine Birds. An Integrated Approach, Springer-Verlag, Berlin, Heidelberg, 1990, pp. 145-155. 